\title{
Acoustic cues of palatalisation in plosive + lateral onset clusters
}

\author{
Daniela Müller ${ }^{1}$, Sidney Martin Mota ${ }^{2}$ \\ ${ }^{1}$ CLLE-ERSS, Université de Toulouse 2 - Le Mirail, Toulouse, France \& Romanisches Seminar, \\ Ruprecht-Karls-Universität Heidelberg, Germany \\ ${ }^{2}$ Escola Oficial d'Idiomes de Tarragona, Spain \\ daniela.mullerduniv-tlse2.fr \\ smart47@xtec.cat
}

\begin{abstract}
Palatalisation of $/ \mathrm{l} / \mathrm{in}$ obstruent + lateral onset clusters in the absence of a following palatal sound has received a considerable amount of attention from historical linguistics. The phonetics of its development, however, remains less wellinvestigated. This paper aims at studying the acoustic cues that could have led plosive + lateral onset clusters to develop palatalisation. It is found that onset clusters with velar plosives favour palatalisation more than labial + lateral clusters, and that a high degree of darkness diminishes the likelihood of palatalisation to take place.
\end{abstract}

Index Terms: laterals, palatalisation, sound change

\section{Introduction}

In historical linguistics, /1/-palatalisation in the complex onset (obstruent+lateral) refers to the phenomenon where /1/ palatalises in absence of a direct palatalising trigger (i.e. without a following vowel /i, e/). This sound change has taken place in several Romance languages and dialects $[1,2,3]$, Thai dialects [4] as well as in the evolution of Tibeto-Burman [5]. Examples include Italian "piazza", "bianco", "fiore", "chiave", "ghiaccio" < Vulgar Latin "platea", (germ.) "*blank", "flore", "clave", "glacie", respectively.

It is commonly assumed that the sound change originated in the velar + lateral onset clusters $/ \mathrm{kl}, \mathrm{gl} /$ and only then affected the labial + lateral clusters /pl, bl, fl/ [6]. This is supported by dialectological evidence $[1,4,5,6,7]$ : languages or dialects that palatalise $/ \mathrm{pl}, \mathrm{bl}, \mathrm{fl} /$ also palatalise $/ \mathrm{kl}, \mathrm{gl} /$, but the reverse is not true.

The likelihood of palatalisation occurring with velars rather than with labials has often received an explanation based on production (though often without experimental evidence), e.g. [1, 3, 8]. According to this hypothesis, an assimilation in the point of articulation would have taken place while transiting from the tongue dorsum gesture for the velar plosive to the tongue tip gesture for the alveolar lateral. Both tongue gestures would have met half-way, thus producing a sequence of palatalised velar obstruent + palatalised lateral. Once this stage is attained, the sequence would evolve into velar + yod through articulatory simplification.

Sound change, however, is not only due to articulatory changes, but also (and ultimately) to what hearers (mis)perceive $[9,10]$. The intuitive answer to the questions why obstruent + lateral onset clusters palatalise in the absence of a palatal vowel and, more specifically, why velar obstruent + lateral clusters palatalise more readily than labial obstruent + lateral clusters would be that velar + lateral clusters 'sound more palatal(ised)' than labial + lateral clusters.

A related question is that of exploring how the degree of overall darkness/clearness of the alveolar lateral in a particular language is related to the probability of palatalisation in the onset cluster. We do not see darkness or clearness of the lateral as a categorical distinction, but rather as a gradient phenomenon [11]. A dark /l/ is generally thought to be highly constrained in its articulation of the tongue body gesture and therefore resistant to coarticulation $[12,13]$. This would imply that a language with an overall dark /1/ would be less likely to undergo /1/-palatalisation in a complex onset cluster than a language with overall clear $/ 1 / \mathrm{s}$.

The phenomenon of /1/ palatalisation in complex onset clusters was subject to an acoustic study in 1964 [14] and in 1978 [15]. These studies, however, investigated neither the influence of place of articulation nor the degree of darkness/clearness on the palatalisation process. Moreover, they both ultimately relied on visual inspection, comparing $\mathrm{C}$ + lateral and $\mathrm{C}+$ yod clusters in spectrographic representations. Our study will thus explore the poorly studied acoustic aspects of the sound change of /1/-palatalisation in complex onset clusters.

In summary, our experiment will investigate whether:

(a) the place of articulation of the preceding consonant has a significant influence on the palatalisation process, as predicted by the dialectological data;

(b) the degree of darkness/clearness of /l/ has an influence on the palatalisation process, more specifically whether dark laterals hinder palatalisation more than clear laterals.

\section{Method}

\subsection{Subjects}

We chose to avoid studying dialects of Occitan and Catalan which have undergone /1/-palatalisation in the past, since these dialects may still have a tendency towards this phenomenon.

We therefore recruited 2 speakers of Occitan (Western Lengadocian) - SC (male, in his 50s, from Vilafranca-deRoergue; Aveiron) and XB (male, in his 20s, from Castras; Tarn) - and 2 speakers of Catalan - MB (male, in his 60s, from Vall Fosca) and JM (male, in his 40s, from Conca de Barberà).

In order to test whether the two language varieties taken as representatives of a clear-/1/-language (Occitan) and of a dark/1/-language (Catalan) really differed in terms of darkness/clearness, F2-F1 in intervocalic laterals $(\mathrm{p}<0.01)$ was compared (in the words "talir", "talar" and "talon/talun"). One-way ANOVA $(\mathrm{F}(1,58)=9,425), \mathrm{p}<0.01)$ showed that laterals in Occitan (mean $=8.16 ; \mathrm{SD}=1.87$ ) were significantly clearer than the ones in Catalan $($ mean $=6.82 ; \mathrm{SD}=1.51$ ). 


\subsection{Material}

Speakers read a list of disyllabic nonsense words, in which the target consonant clusters in Table 1 were included for posterior analysis. The vowel following the consonant cluster was controlled for $(/ \mathrm{a} /$ and $/ \mathrm{u} /)$. Tokens where the onset cluster was followed by /i/ were also recorded, but not included in the analysis, since comparisons to / $\mathrm{Cji} /$ tokens were not possible, as / $\mathrm{Cji} /$ sequences are ruled out by phonotactic constraints in both languages and cannot even be rendered by means of orthography. Acoustic analysis of the /Cli/ tokens (results are not reported in this paper) revealed partial anticipatory palatalisation on the lateral.

Table 1. Target consonant clusters in the two languages.

\begin{tabular}{|c|c|c|c|}
\hline$/ \mathrm{Cl} /$ & $/ \mathrm{Cl} /$ & $/ \mathrm{Cj} /$ & $/ \mathrm{Cj} /$ \\
voice $(+)$ & voice(-) & voice(+) & voice(-) \\
$/ \mathrm{gl} /$ & $/ \mathrm{kl} /$ & $/ \mathrm{gj} /$ & $/ \mathrm{kj} /$ \\
$/ \mathrm{bl} /$ & $/ \mathrm{pl} /$ & $/ \mathrm{bj} /$ & $/ \mathrm{pj} /$ \\
\hline
\end{tabular}

The actual tokens utilised in the experiment for Catalan and Occitan were as follows (Table 2):

Table 2. Tokens in the two languages (orthographic version).

\begin{tabular}{|l|c|c|c|}
\hline \multicolumn{2}{|c|}{ Catalan } & \multicolumn{2}{c|}{ Occitan } \\
\hline /Cl/ & $/ \mathrm{Cj} /$ & $/ \mathrm{Cl} /$ & $/ \mathrm{j} /$ \\
blata & biata & blata & biata \\
bluta & biuta & blota & biota \\
plata & piata & plata & piata \\
pluta & piuta & plota & piota \\
clata & quiata & clata & quiata \\
cluta & quiuta & clota & quiota \\
glata & guiata & glata & guiata \\
gluta & guiuta & glota & guiota \\
\hline
\end{tabular}

\subsection{Experiment design}

Speakers sat in front of a PC and read a list of randomised tokens from a PowerPoint slide presentation at a self-chosen normal speech rate. Slides with a single token at a time changed every 4 seconds.

The Catalan data were recorded at a $44 \mathrm{kHz}$ sampling rate, using a Behringer XM2000 microphone, connected to an MAudio Pre-Amp Audio Interface, and the audio editor and recorder Audacity 1.2.6.

The Occitan data were recorded at the DTICE of the Universitat de Tolosa 2 - Lo Miralh on a Tascam DA-P1 Digital Audio Tape Recorder via a Soundcraft Delta Ave audio mixer, in a sound-proof chamber, using high quality microphones by SE Electronics (SE 2200 A). The data were also digitised at a rate of $44 \mathrm{kHz}$ with the Nétia Radio-Assiste 7.11 programme and a Yamaha 01V digital audio mixer.

A total number of eight tokens per target word were recorded. The best five ones (judged by visual and auditory inspection) were selected for further acoustic analysis, using Praat 4.5.

\subsection{Analysis}

Data from the acoustic signal were extracted in the following way:

- The first $20 \mathrm{msec}$ starting from the onset of the /1/ and /j/ were selected.

- $\mathrm{Hz}$ values were obtained for F1, F2, F3 and F4 at 0 msec, $10 \mathrm{msec}$ and $20 \mathrm{msec}$ after the onset of $/ \mathrm{l} /$ and $/ \mathrm{j} /$. Once the data were obtained $\mathrm{Hz}$ values were converted to Bark values, using the equation proposed by [16], assuming a similar transformation in the ear of the listener.

For each of the target consonants and for each of the three time steps $(\mathrm{T} 1=0 \mathrm{msec}, \mathrm{T} 2=10 \mathrm{msec}, \mathrm{T} 3=20 \mathrm{msec}$ after lateral or yod onset), the distance between F2 and F1 (F2-F1) was calculated in order to determine the degree of velarity/darkness - palatality/clearness of the lateral, assuming that the magnitude of F2-F1 is directly related to degree of palatalisation and inversely related to degree of velarisation (see Tables 3a and 3b for a summary). F3-F2 and F4-F3 distances were also calculated and tested, but didn't yield consistent results and are therefore not reported in this paper.

The data were analysed using ANOVAs $(\mathrm{p}<0.01)$ with $\mathrm{F} 2-\mathrm{F} 1$ as the dependent variable and target consonant (lateral vs. yod), preceding consonant $(/ \mathrm{k}, \mathrm{g}, \mathrm{p}, \mathrm{b} /)$ and following vowel $(/ \mathrm{a}, \mathrm{u} /)$ as independent variables. In addition, the data of each subject were analysed separately in order to control for individual differences. Posthoc comparisons ( $t$-tests, $\mathrm{p}<0.01$ ) were performed for the pairs /Cl/ vs / $\mathrm{Cj} /$ (see Table 2).

Table 3a. Mean values in Bark (M) and standard deviations (SD) for /Cl/ clusters at the three time steps (T1, T2, T3) from the four subjects (Oc-XB, Oc-SC, Cat$M B, C a t-J M) ; O c=$ Occitan, Cat $=$ Catalan.

\begin{tabular}{|c|c|c|c|c|c|c|c|c|c|}
\hline & \multicolumn{2}{|c|}{ Oc-XB } & \multicolumn{2}{|c|}{ Oc-SC } & \multicolumn{2}{|c|}{ Cat-MB } & \multicolumn{2}{|c|}{ Cat-JM } \\
\hline & & $\mathrm{M}$ & SD & $\mathrm{M}$ & SD & $\mathrm{M}$ & SD & $\mathrm{M}$ & SD \\
\hline \multirow[t]{3}{*}{ bla } & $\mathrm{T} 1$ & 6.9 & 0.3 & 7.8 & 0.5 & 8.2 & 1.8 & 6.8 & 0.3 \\
\hline & $\mathrm{T} 2$ & 7.1 & 0.3 & 7.5 & 0.1 & 7.2 & 0.4 & 6.7 & 0.4 \\
\hline & T3 & 7.1 & 0.2 & 7.5 & 0.4 & 7.2 & 0.5 & 6.7 & 0.1 \\
\hline \multirow[t]{3}{*}{ blu } & T1 & 6.9 & 0.4 & 6.9 & 0.5 & 6.5 & 0.8 & 7.1 & 0.7 \\
\hline & $\mathrm{T} 2$ & 6.5 & 0.1 & 7.2 & 0.5 & 6.4 & 0.7 & 6.6 & 0.4 \\
\hline & T3 & 6.5 & 0.2 & 7.1 & 0.5 & 6.4 & 0.7 & 6.5 & 0.4 \\
\hline \multirow[t]{3}{*}{ pla } & $\mathrm{T} 1$ & 6.8 & 0.2 & 7.3 & 0.3 & 6.8 & 0.8 & 5.6 & 1.1 \\
\hline & $\mathrm{T} 2$ & 6.8 & 0.2 & 7.1 & 0.5 & 6.7 & 0.6 & 6.2 & 0.6 \\
\hline & T3 & 6.6 & 0.4 & 7.1 & 0.6 & 6.3 & 0.3 & 6.1 & 0.2 \\
\hline \multirow[t]{3}{*}{ plu } & $\mathrm{T} 1$ & 6.9 & 0.6 & 6.5 & 0.6 & 7.9 & 1.3 & 7.1 & 0.9 \\
\hline & $\mathrm{T} 2$ & 6.6 & 0.2 & 6.2 & 0.4 & 7.4 & 2.1 & 7.3 & 0.8 \\
\hline & T3 & 6.4 & 0.3 & 6.1 & 0.3 & 7.4 & 1.1 & 7.1 & 0.6 \\
\hline \multirow[t]{3}{*}{ kla } & $\mathrm{T} 1$ & 7.3 & 0.2 & 8.1 & 0.5 & 7.6 & 0.3 & 7.1 & 0.9 \\
\hline & $\mathrm{T} 2$ & 6.9 & 0.2 & 7.3 & 0.2 & 6.8 & 0.4 & 6.2 & 0.3 \\
\hline & T3 & 6.5 & 0.6 & 6.9 & 0.4 & 6.9 & 0.6 & 5.9 & 0.4 \\
\hline \multirow[t]{3}{*}{ klu } & $\mathrm{T} 1$ & 7.3 & 0.3 & 7.1 & 0.5 & 8.2 & 2.3 & 7.2 & 1.6 \\
\hline & $\mathrm{T} 2$ & 7.1 & 0.2 & 7.1 & 0.7 & 6.5 & 1.1 & 7.3 & 1.5 \\
\hline & $\mathrm{T} 3$ & 6.8 & 0.2 & 7.1 & 0.6 & 6.9 & 0.4 & 7.2 & 0.8 \\
\hline \multirow[t]{3}{*}{ gla } & $\mathrm{T} 1$ & 8.5 & 0.3 & 8.7 & 0.5 & 7.1 & 0.3 & 7.3 & 0.3 \\
\hline & $\mathrm{T} 2$ & 8.1 & 0.2 & 8.1 & 0.5 & 7.4 & 0.4 & 6.7 & 0.2 \\
\hline & T3 & 7.5 & 0.2 & 7.5 & 0.3 & 7.2 & 0.3 & 6.5 & 0.3 \\
\hline \multirow[t]{3}{*}{ glu } & $\mathrm{T} 1$ & 7.2 & 0.3 & 9.3 & 1.3 & 7.1 & 2.2 & 6.6 & 0.8 \\
\hline & $\mathrm{T} 2$ & 7.4 & 0.3 & 7.9 & 0.8 & 6.6 & 1.4 & 6.6 & 0.4 \\
\hline & T3 & 7.2 & 0.4 & 7.6 & 0.5 & 6.5 & 0.6 & 6.4 & 0.3 \\
\hline
\end{tabular}


Table 3b. Mean values in Bark $(M)$ and standard deviations $(S D)$ for $/ \mathrm{Cj} /$ clusters at the three time steps (T1, T2, T3) from the four subjects (Oc-XB, Oc-SC, Cat$M B$, Cat $-J M), O c=$ Occitan, Cat $=$ Catalan

\begin{tabular}{|c|c|c|c|c|c|c|c|c|c|}
\hline & \multicolumn{2}{|c|}{ Oc-XB } & \multicolumn{2}{|c|}{ Oc-SC } & \multicolumn{2}{|c|}{ Cat-MB } & \multicolumn{2}{|c|}{ Cat-JM } \\
\hline & & $\mathrm{M}$ & SD & $\mathrm{M}$ & SD & $\mathrm{M}$ & SD & $\mathrm{M}$ & SD \\
\hline \multirow[t]{3}{*}{ bja } & T1 & 9.8 & 0.2 & 10.5 & 0.8 & 12.8 & 0.8 & 12.4 & 0.2 \\
\hline & $\mathrm{T} 2$ & 9.5 & 0.3 & 11.2 & 0.8 & 12.7 & 0.1 & 12.4 & 0.2 \\
\hline & T3 & 9.3 & 0.3 & 11.6 & 0.2 & 12.8 & 0.2 & 12.4 & 0.1 \\
\hline \multirow[t]{3}{*}{ bju } & T1 & $\begin{array}{l}10 . \\
1\end{array}$ & 0.1 & 10.6 & 0.5 & 12.5 & 0.5 & 11.9 & 1.0 \\
\hline & $\mathrm{T} 2$ & 9.9 & 0.2 & 10.5 & 0.6 & 12.7 & 0.1 & 12.4 & 0.1 \\
\hline & T3 & 9.8 & 0.2 & 10.1 & 0.4 & 12.6 & 0.1 & 12.4 & 0.1 \\
\hline \multirow[t]{3}{*}{ pja } & T1 & 9.3 & 0.4 & 11.1 & 0.5 & 10.9 & 2.3 & 12.6 & 0.1 \\
\hline & $\mathrm{T} 2$ & 9.1 & 0.4 & 11.1 & 0.4 & 12.5 & 0.4 & 12.5 & 0.1 \\
\hline & T3 & 8.4 & 0.6 & 10.7 & 0.6 & 12.8 & 0.2 & 12.5 & 0.1 \\
\hline \multirow[t]{3}{*}{ pju } & T1 & $\begin{array}{l}10 . \\
3\end{array}$ & 0.6 & 10.5 & 0.4 & 12.5 & 0.1 & 12.4 & 0.4 \\
\hline & $\mathrm{T} 2$ & 9.7 & 0.2 & 10.5 & 0.4 & 12.4 & 0.1 & 12.4 & 0.2 \\
\hline & $\mathrm{T} 3$ & 9.5 & 0.3 & 11.1 & 0.4 & 12.4 & 0.1 & 12.3 & 0.3 \\
\hline \multirow[t]{3}{*}{ kja } & $\mathrm{T} 1$ & 8.7 & 0.3 & 10.2 & 0.9 & 12.8 & 0.1 & 12.9 & 0.4 \\
\hline & $\mathrm{T} 2$ & 7.8 & 0.4 & 10.3 & 0.7 & 13.1 & 0.3 & 12.9 & 0.3 \\
\hline & T3 & 6.3 & 0.6 & 9.2 & 1.2 & 12.9 & 0.2 & 12.8 & 0.1 \\
\hline \multirow[t]{3}{*}{ kju } & T1 & 9.4 & 0.2 & 10.1 & 0.5 & 12.7 & 0.5 & 12.4 & 0.5 \\
\hline & $\mathrm{T} 2$ & 8.9 & 0.3 & 10.1 & 0.1 & 12.6 & 0.7 & 11.8 & 0.3 \\
\hline & $\mathrm{T} 3$ & 7.7 & 0.8 & 10.1 & 0.7 & 12.6 & 0.9 & 12.5 & 0.1 \\
\hline \multirow[t]{3}{*}{ gja } & T1 & $\begin{array}{l}10 . \\
1\end{array}$ & 0.7 & 10.2 & 1.3 & 13.3 & 0.1 & 12.7 & 0.3 \\
\hline & $\mathrm{T} 2$ & 9.2 & 0.5 & 10.1 & 0.1 & 13.1 & 0.2 & 12.7 & 0.2 \\
\hline & T3 & 9.5 & 0.9 & 10.5 & 0.6 & 13.1 & 0.1 & 12.7 & 0.2 \\
\hline \multirow[t]{3}{*}{ gju } & $\mathrm{T} 1$ & $\begin{array}{l}10 . \\
2\end{array}$ & 0.9 & 10.1 & 0.3 & 13.3 & 0.3 & 12.6 & 0.2 \\
\hline & $\mathrm{T} 2$ & $\begin{array}{l}10 . \\
4\end{array}$ & 0.8 & 10.3 & 0.5 & 13.2 & 0.1 & 12.5 & 0.2 \\
\hline & $\mathrm{T} 3$ & $\begin{array}{l}10 . \\
6\end{array}$ & 0.5 & 10.1 & 0.8 & 13.1 & 0.2 & 12.6 & 0.2 \\
\hline
\end{tabular}

\section{Results}

Factorial ANOVAs (see Table 4 for a summary of the main effects) yielded a significant effect of the target consonant (lateral vs. yod) on F2-F1 for the two Occitan speakers and the two Catalan speakers. Generally speaking, the following vowel fails to have a significant effect on F2-F1. Interactions between the main factors have been observed in the two varieties, thus posthoc comparisons have been performed.

Table 4: Summary of the main effects in the three subjects at the three timesteps; significant effects (*), non-significant effects $(X) ; p<0.01$.

\begin{tabular}{|l|l|l|l|l|l|l|l|l|l|l|l|l|}
\cline { 2 - 9 } \multicolumn{1}{c|}{} & \multicolumn{3}{l|}{ Oc-XB } & \multicolumn{3}{c|}{ Oc-SC } & \multicolumn{3}{c|}{ Cat-MB } & \multicolumn{3}{c|}{ Cat-JM } \\
\hline Factors & 1 & 2 & 3 & 1 & 2 & 3 & 1 & 2 & 3 & 1 & 2 & 3 \\
\hline $\begin{array}{l}\text { Target } \\
\text { consonant }\end{array}$ & $*$ & $*$ & $*$ & $*$ & $*$ & $*$ & $*$ & $*$ & $*$ & $*$ & $*$ & $*$ \\
\hline $\begin{array}{l}\text { Preceding } \\
\text { consonant }\end{array}$ & $*$ & $*$ & $*$ & $*$ & $\mathrm{X}$ & $*$ & $\mathrm{X}$ & $*$ & $*$ & $\mathrm{X}$ & $\mathrm{X}$ & $\mathrm{X}$ \\
\hline $\begin{array}{l}\text { Following } \\
\text { vowel }\end{array}$ & $\mathrm{X}$ & $*$ & $*$ & $\mathrm{X}$ & $\mathrm{X}$ & $\mathrm{X}$ & $\mathrm{X}$ & $\mathrm{X}$ & $\mathrm{X}$ & $\mathrm{X}$ & $\mathrm{X}$ & $\mathrm{X}$ \\
\hline
\end{tabular}

Posthoc comparisons (see Table 5) showed that, in the case of the labial + lateral onset clusters, the resemblance with the corresponding labial + yod clusters was fairly inexistent in both the Catalan and Occitan data. That is, their F2-F1 distance was significantly different at the $\mathrm{p}<0.01$ level.
This was not so for the velar + lateral onset clusters compared to the velar + yod ones, more specifically $/ \mathrm{kl} / \mathrm{vs} / \mathrm{kj} /$ (see Figure 1 and Table 5). While the Catalan utterances showed fairly consistent non-similarity of both clusters, the Occitan ones rarely reached the $<0.001$ level, as in $/ \mathrm{kla} /-/ \mathrm{kja} /$ time step 3 for speaker XB $(t=0,602)$ as well as in /glu/ - /gju/ time step 1 for speaker $\mathrm{SC}(\mathrm{t}=1,290)$ (see Table 5).

Table 5. Results from Occitan (Oc) and Catalan (Cat); non-significant comparisons at a p-level $<0.01$ highlighted in grey.

\begin{tabular}{|c|c|c|c|c|c|}
\hline $\begin{array}{c}\text { pairs of } \\
\text { clusters }\end{array}$ & $\begin{array}{c}\text { Time } \\
\text { steps }\end{array}$ & Oc - XB & Oc-SC & Cat-MB & Cat-JM \\
\hline $\begin{array}{c}\text { bla - } \\
\text { bja }\end{array}$ & 1 & $<0.001$ & $<0.001$ & $<0.001$ & $<0.001$ \\
& 2 & $<0.001$ & $<0.001$ & $<0.001$ & $<0.001$ \\
& 3 & $<0.001$ & $<0.001$ & $<0.001$ & $<0.001$ \\
blu - & 1 & $<0.001$ & $<0.001$ & $<0.001$ & $<0.001$ \\
bju & 2 & $<0.001$ & $<0.001$ & $<0.001$ & $<0.001$ \\
& 3 & $<0.001$ & $<0.001$ & $<0.001$ & $<0.001$ \\
pla - & 1 & $<0.001$ & $<0.001$ & $>0.01$ & $<0.001$ \\
pja & 2 & $<0.001$ & $<0.001$ & $<0.001$ & $<0.001$ \\
& 3 & $<0.001$ & $<0.001$ & $<0.001$ & $<0.001$ \\
plu - & 1 & $<0.001$ & $<0.001$ & $<0.001$ & $<0.001$ \\
pju & 2 & $<0.001$ & $<0.001$ & $<0.01$ & $<0.001$ \\
& 3 & $<0.001$ & $<0.001$ & $<0.001$ & $<0.001$ \\
\hline gla - & 1 & $>0.01$ & $>0.01$ & $<0.001$ & $<0.001$ \\
gja & 2 & $<0.01$ & $<0.01$ & $<0.001$ & $<0.001$ \\
& 3 & $<0.01$ & $<0.001$ & $<0.001$ & $<0.001$ \\
& 1 & $<0.001$ & $>0.01$ & $<0.001$ & $<0.001$ \\
glu - & 1 & $<0.001$ & $<0.001$ & $<0.01$ & $<0.001$ \\
gju & 2 & $<0.001$ & $<0.001$ & $<0.001$ & $<0.001$ \\
& 3 & $<0.001$ & $<0.001$ & $<0.001$ & $<0.001$ \\
kla - & 1 & $<0.001$ & $<0.01$ & $<0.001$ & $<0.001$ \\
kja & 2 & $>0.01$ & $<0.001$ & $<0.001$ & $<0.001$ \\
& 3 & $>0.01$ & $>0.01$ & $<0.001$ & $<0.001$ \\
& 1 & $<0.001$ & $<0.01$ & $<0.001$ & $<0.001$ \\
& 3 & $>0.01$ & $>0.01$ & $<0.001$ & $<0.001$ \\
\hline
\end{tabular}

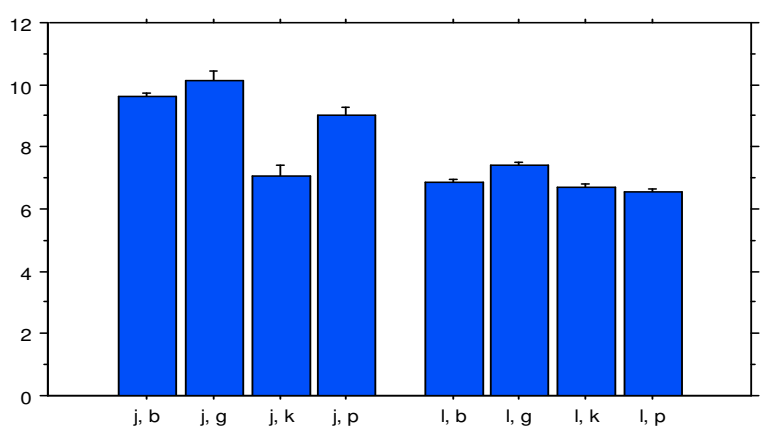

Figure 1: Bar plot displaying mean F2-F1 (Bark) as a function of consonantal context (plosive + lateral/yod) at timestep 2; subject $O c-X B$. 


\section{Discussion and Conclusions}

Hypothesis (a): Velar plosives favour palatalisation of /// in onset clusters more than labial plosives. The pairwise comparisons of plosive + lateral and plosive + yod clusters showed, as suggested by dialectological data, that velar + lateral and velar + yod clusters may resemble each other during the first few milliseconds of the sound (see Table 5), with the consequence that listeners may easily confound them. This could not be seen in labial + lateral clusters.

As for the articulatory configurations that may cause these acoustic similarities in the transition from the velar plosive into the lateral approximant, we could hypothesise that there seems to be a tendency for velars to undergo closure fronting during release of the stop which would create the palatalised acoustic structures in the first part of the lateral.

Hypothesis (b): Dark /l/ is less prone to palatalisation than clear $/ l$. This hypothesis is also accepted. It corroborates the assumption that the resistance for dark /l/ to undergo palatalisation (becoming clearer) is due to its being highly constrained in its tongue body configuration, as pointed out in the introduction. This coincides with the ANOVA results, which show no significant influence of the vowel on F2-F1 distance for the Catalan speakers. Interestingly enough, in one of the Occitan speakers (SC, cf. Table 4), no significant influence of the vowel on the lateral could be found either, despite his /l/ being clear. Clear /1/s resistant to vowelcoarticulation have been found in the literature before, and it has been hypothesised that their lingual posterior configuration is also rather constrained, though not as constrained as for dark /1/ $[17,18]$.

While acoustic evidence could be adduced for the occurrence of /1/-palatalisation in the velar plosive + lateral onset clusters, the reasons for palatalisation in the labial + lateral clusters - a much less widespread phenomenon dependent on palatalisation in the velar + lateral clusters - are not yet clear. Following Ohala's model of sound change [9, 10], we would also expect to find some similarities in labial + lateral and labial + yod clusters if one does not wish to resort to the argument of analogical sound change [2]. These similarities, however, may be subtler than in the case of palatalisation in velar + lateral clusters, given their more restricted geographical distribution. Moreover, epenthesis of a lateral element is known to have taken place in some labial + yod clusters in Slavic languages [19] and in Romance dialects [20], while such a development has never been attested for velar + yod clusters, as far as we know. Future research will focus on the relationship between the phenomenon of /1/palatalisation in onset clusters and ///-epenthesis in obstruent + yod clusters.

\section{Acknowledgements}

This research was in part made possible by a doctoral fellowship grant of the state of Baden-Württemberg, Germany accorded to the first author. We would like to thank twenty or so subscribers to LinguistList for discussion of the phenomenon, and among them particularly Daniel Recasens for his interest and advice on this study.

\section{References}

[1] Repetti, L. and Tuttle, E. F., "The evolution of Latin PL, BL, FL and CL, GL in Western Romance", Studi Mediolatini e Volgari 33: 53-115, 1987
[2] Tuttle, E. F., "The development of PL, BL, and FL in ItaloRomance: distinctive features and geolinguistic patterns", Revue de Linguistique Romane 39: 400-431, 1975.

[3] Rousselot, P. J., «Les modifications phonétiques du langage, étudiées dans le patois d'une famille de Cellefrouin (Charente) », Welter, 1891.

[4] Li, F.-K., "Consonant clusters in Tai", Language 30 (3): 368 379, 1954.

[5] Matisoff, J. A., "Handbook of Proto-Tibeto-Burman: System and philosophy of Sino-Tibetan reconstruction", University of California Press, 2003.

[6] Meyer-Lübke, W., „Die Schicksale des lateinischen L im Romanischen. § 5: Konsonant + L“, Berichte der Sächsischen Akademie in Leipzig 86: 43-63, 1934.

[7] Müller, D., ,Sound patterns in Lemosin and Auvernhat Occitan. The lateral /1/ and its developments", $\mathrm{PhD}$ thesis, Université de Toulouse 2 - Le Mirail, in preparation.

[8] Straka, G., «Contribution à la description et à l'histoire des consonnes L », in Les sons et les mots. Choix d'études de phonétique et de linguistique. Publié par les collègues, les élèves et les amis de l'auteur, Klincksieck, 363-422, 1979.

[9] Ohala, J. J., "The phonetics of sound change", in C. Jones [Ed], Historical Linguistics: Problems and Perspectives, 237-278, Longman, 1993.

[10] Ohala, J. J., "Sound change as nature's speech perception experiment", Speech Communication 13: 155-161, 1993.

[11] Recasens, D., "Darkness in /1/ as a scalar phonetic property: implications for phonology and articulatory control", Clinical Linguistics \& Phonetics 18 (6-8): 593-603, 2004.

[12] Recasens, D. and Espinosa, A., "Articulatory, positional and coarticulatory characteristics for clear /1/ and dark /1/: evidence from two Catalan dialects", Journal of the International Phonetic Association 35 (1): 1-25, 2005.

[13] Recasens, D. and Farnetani, E., "Articulatory and acoustic properties of different allophones of /1/ in American English, Catalan, and Italian", Proceedings of the International Conference on Spoken Language Processing 90 (2): 961-964, Acoustical Society of Japan, 1990.

[14] Von Essen, O., "An Acoustic Explanation of the Sound Shift [t] $>[\mathrm{u}]$ and $/ \mathrm{l} />[\mathrm{i}]$ ", in D. Abercrombie, D. B. Fry, P. A. D. MacCarthy, N. C. Scott and J. L. M. Trim [Eds], In Honour of Daniel Jones, 53-58, Longman, 1964.

[15] Javkin, H. P., "Phonetic Universals and Phonological Change", $\mathrm{PhD}$ thesis, University of California at Berkeley, UMI Dissertation Services, 1978.

[16] Traunmüller, H., "Analytical expressions for the tonotopic sensory scale", Journal of the Acoustical Society of America 88: 97-100, 1990.

[17] Recasens, D., Fontdevila, J. and Pallarès, M. D., "Linguopalatal coarticulation and alveolar-palatal correlations for velarized and non-velarized /l/", Journal of Phonetics 24: 165-185, 1996.

[18] Recasens, D., Fontdevila, J. and Pallarès, M. D., "Velarization degree and coarticulatory resistance for /1/ in Catalan and German", Journal of Phonetics 23: 37-52, 1995.

[19] Carlton, T. R., "Introduction to the phonological history of the Slavic languages", Slavica Publishers, 1991.

[20] Rohlfs, G., „Ein Problem der vergleichenden Lautgeschichte“, Zeitschrift für romanische Philologie 42: 69-71, 1922. 